\title{
Research council offers hope for astronomers
}

THE worst fears of the British astronomical community, that Britain might abandon observation in the Southern Hemisphere, may have been allayed by last week's meeting of the Science and Engineering Research Council (SERC). Some consider that the council was favourably disposed to the submission of its Astronomy, Space and Radio (ASR) Board for funds over the next five years, at a time when a combination of exchange rate fluctuations and pressure on the council's budget from other areas of science and from engineering have never been so acute. But the forward-look process has revealed differing perceptions of priority within the council's committees. Moreover, the longterm outlook is not yet certain, as the Advisory Board for the Research Councils (ABRC) has yet to consider the council's proposals, and some of the options involve international agreements.

By all accounts, the January meeting of the ASR board was an emotionally charged affair. Faced with the task of producing a list of priorities for the council, the board's subcommittees had thought the unthinkable and ordered their respective research programmes on strictly scientific grounds. It was the ASR's board's task to co-ordinate these shopping lists into a package for presentation to the council. In the event, there was a heated debate over proposals for ground-based optical astronomy.

Two of the most important telescopes currently at the disposal of British astronomers are the Anglo-Australian Telescope (AAT) and the UK Schmidt telescope, both in Australia. Both have proved highly successful and are generally agreed to be capable of producing world class results for several years yet. In the next few years, however, two new telescopes on La Palma in the Canary Islands - the $2.5 \mathrm{~m}$ Isaac Newton and the $4.2 \mathrm{~m}$ William Herschel - are due jointly to provide a fírst-class facility in the Northern Hemisphere.

At the January meeting of the ASR board, a certain polarization developed between those who favoured the retention of Southern Hemisphere activity those who felt that it would be better to concentrate resources at a variety of wavelengths in the Northern Hemisphere. This option would allow more collaboration, for example, between optical, infrared and radio astronomers, all of whom are strongly represented in Britain.

The prevailing view was that the Northern Hemisphere option would be the easier to sell to backers, chiefly on the grounds that it would be more easily managed. The final package that went to the council was broadly split into three. The worst-case, or lower guideline option, included studentships and grants, data processing, support for approved space projects such as the X-ray satellite ROSAT and the Comet Halley explorer Giotto, the current subscription to ESA, the European Space Agency (the 5 per cent increase recently agreed will not be paid by SERC), and the Northern Hemisphere telescopes and radars. This package would represent a 10 per cent cut in current plans.

The centre guideline option, representing the current spending level, would add support for ESA's future space programme as spelt out in its "Horizon 2000 " report. The third component of the ASR board's list, and relatively low in its priorities, includes Solar System space research and Southern Hemisphere facilities.

At last week's meeting, however, the council stopped short of recommending a withdrawal from the Southern Hemisphere observatories, partly as a result of the strength of the scientific case and partly because of the international implications. Broadly speaking, the council favoured rather more than the central guideline package. One option being investigated for several of SERC's major facilities is that working time should be sold abroad to recoup costs. And, in a move that will bring weary shrugs of resignation from the staffs of the two British observatories in Sussex and at Edinburgh, yet another committee is to be set up to decide their future. This time, however, its committee is apparently to be chaired by SERC's chairman, $\mathrm{Sir}$ John Kingman, who is said to want this resolved before he leaves later this year.

Philip Campbell

\section{US/Canada stand-off (contd)}

Acid rain

Washington

LAST week's agreement between the United States and Canada on acid rain appears to represent no shift in the Reagan administration's policy: research, yes; controls, no. Canada, meanwhile, is accelerating its unilateral efforts to reduce emissions sources responsible for acid deposition without waiting for reciprocal action from the United States.

What last week's agreement does is to create two "special envoys" who will "examine" the acid rain issue and report within a year. The Canadians hope they will become negotiators; but the announcement suggests their role will be limited to consultation. For months, the Canadian government had made clear that acid rain would be at the top of the summit agenda. And while Canadian officials say the agreement is a hopeful sign, environmentalists have already dismissed it as a contrivance that allows Prime Minister Brian Mulroney, under considerable domestic pressure to achieve results on the acid rain problem, to claim that he did not come away completely empty-handed.

Earlier this month, however, the Canadian government was able to take credit for some more tangible steps towards acid-rain control. The federal government agreed to allocate $\$ 150$ million to aid the smelting industry, Canada's major contributor to acid deposition, to reduce sulphur dioxide emissions. The provincial governments and industry will provide the remaining portion of the estimated $\$ 1,500-2,000$ million. And, although it is only a minor source of the problem, Canada will as of September 1987 require $\mathrm{NO}_{x}$ emissions from cars and light trucks to match the stricter US standards; this is seen more as a political move to remove US objections that Canada was demanding US action while refusing to clean up its own house.

The Canadian government says that these steps will enable the country to reach its earlier-stated goal of reducing wet sulphur deposition to $20 \mathrm{~kg}$ per hectare per year in the sensitive eastern provinces but only if the United States takes "compatible" action. Canada's reduction plans, which will cut total sulphur dioxide emissions by approximately one-half, will be completed by 1994 .

Although US officials do not challenge the Canadian assertion that at least 50 per cent of acid deposition in eastern Canada is the result of emissions from US power plants (while only 10 per cent of acid deposition in the northeastern United States originates in Canada), the Reagan administration insists that more research must be done before the expense of new sulphur controls can be justified. The US argument is that not enough is known about the linearity of the atmospheric response or about how quickly lakes subjected to acid deposition actually acidify. If the lakes respond very quickly, they argue, then it is possible that virtually all susceptible lakes are already acidified, and new emission controls will make no difference.

Canada has been pressing for a 50 per cent reduction in US sulphur emissions from appropriate regions. A plan proposed by former Environmental Protection Agency administrator William Ruckelshaus but rejected by the Office of Management and Budget would have cut emissions from midwestern power plants by some 3-5 million tons, which Canada says would have been sufficient. Stephen Budiansky 